$2^{\text {nd }}$ World Conference On Future Of EDUCATION

BRUSSELS, BELGIUM

11-13 September 2020

\title{
Health Training for Parents in the Fight against Passive Smoking
}

\author{
Tanya Popova, Ivanka Stambolova, Milena Iantcheva-Stoycheva, Petya Trendafilova* \\ Medical University - Sofia, Faculty of Public Health, Department of Health Care, Sofia, Bulgaria \\ *Corresponding author
}

\begin{abstract}
.
Health education and training are top priorities in health promotion and can be used as a tool to prevent risk factors for cardiovascular disease. The aim of the paper is to study and analyze passive smoking in childhood and to justify the need for health education for parents. Historical, documentary method, sociological method, statistical methods and method for graphical analysis of the results are used. The study was conducted among 802 parents of children aged 3 to 12 years. The analysis of the data shows that in $17.0 \%$ of children smoking begins in utero, and in $12.0 \%$ it continues during breastfeeding and establishes a statistically significant relationship between smoking during pregnancy and during breastfeeding. Parents are not well informed about the risks of secondhand smoke. Turning children into passive smokers can trigger a number of health problems, including cardiovascular problems at some point in a child's life. There is a need for health education on issues related to passive smoking in children, as we believe that if parents are aware of future health risks, properly and well informed about the consequences, both in the early stages of the child's life and in the future, they would not allow themselves to expose their child to passive smoking, or at least many of them would reduce this risk.
\end{abstract}

Keywords: health education; necessity; cardiovascular diseases; prevention; children. 


\title{
$2^{\text {nd }}$ World Conference On Future of EDUCATION
}

\author{
BRUSSELS, BELGIUM
}

11-13 September 2020

\section{Introduction}

Health education and training of children and their families are the leading priorities of health promotion. The goal of health education is to engage the individual and society to build and lead a healthy lifestyle, which is a major factor in improving health indicators and reducing future morbidity (Борисов et al., 1998. Иванов, 2015. Георгиева). In the current epidemic of cardiovascular diseases (CVD) in Bulgaria, the goals and priorities of health promotion become an integral part of the prevention of risk factors (RF) and the fight against CVD (Попова, 2020. Попова, Бикова, 2017).

Even with the birth of children there is a possibility of various health problems due to hereditary burden and prenatal impact of the RF, as well as factors of the environment in which they live. After birth and the onset of life, the likelihood of developing the disease can be changed under the influence of socio-economic factors, cultural conditions, environmental and working conditions and lifestyle (Попова, 2020. Meredzhanova et al., 2019. Merdjanova et al., 2016).

Health is the highest value and should be a top priority for the family, medical professionals, teachers, society and the state. The role of medical professionals in helping patients maintain a full lifestyle is enormous, but family traditions and training remain in the hands of parents and its role should not be underestimated.

According to B. Tornyova, the family is the first and main bio-psycho-social environment and the most important health educational factor. It forms the upbringing of children and forms the personality with its habits and attitudes to lead a healthy lifestyle. The family shapes the health behavior of children and the future young generation and leaves a lasting impression on the emerging personality. The family, and in particular the parents, have responsibilities and obligations to their children, namely to provide a healthy family environment, to ensure a healthy lifestyle and to form in children a need for a healthy lifestyle (Торньова, Шопов, 2008).

\section{Methods}

The aim of the present study is to study and analyze passive smoking in childhood and to justify the need for health education for parents.

The subject of the study is passive smoking. The object of the study are children and adolescents in the age group from 3 to 6 years and from 7 to 12 years.

\section{Materials and methodology}

The following methods were used to collect the primary information in the study:

- Historical method;

- Documentary method; 


\title{
$2^{\text {nd }}$ World Conference On Future Of EDUCATION
}

\author{
BRUSSELS, BELGIUM
}

11-13 September 2020

- Sociological method - a direct, individual, anonymous survey was conducted, especially questionnaires were developed for this purpose. In order to obtain more reliable information, the study was conducted among parents of children aged 3 to 12 years;

- $\quad$ Statistical methods - descriptive, variation and alternative analysis, testing of statistical hypotheses for dependencies between two category variables, non-parametric method of Man Whitney, graphical analysis to visualize the results.

- Significance level $\alpha=0.05$ is used. The null hypothesis is rejected at a value of $p \leq$ 0.05 .

- $\quad$ The statistical package SPSS (Statistical Package for the Social Sciences) 19.0 is used for statistical processing of the results. MS Office application products were used for tabular and graphical presentation and presentation of the results.

\section{Results and discussion}

The study covered 802 respondents, of which 355 parents of children in the age group from 3 to 6 years and 447 parents of children from 7 to 12 years of age. It was held in 10 settlements on the territory of Bulgaria, 1 medical institution and 28 educational and children's institutions.

The role of passive smoking has been unequivocally proven to cause CVD. Prenatal exposure to cigarette smoke is also considered the equivalent of passive smoking of the fetus and harms its health. This is evidenced by data from a report by the Royal Medical College, where it is reported that nicotine accelerates the heart rate and increases blood pressure of the fetus. A number of authors (Коларова-Янева et al., 2013) report the presence of atherosclerotic changes in the coronary vessels of fetuses and newborns who have died from other diseases whose mothers have smoked. Data from a study conducted in the UK (UK National Child Development Study) prove the link between prenatal exposure to cigarette smoke and the development of diabetes in the future, additional RF for CVD (Константинова, 2011. Василевски et al., 2004. Попова et al., 2015, A). A study of students in Germany found that children who were chronically poisoned with tobacco during their fetal development had a higher incidence of overweight and obesity than those whose mothers did not smoke during pregnancy.

These facts necessitated a study of mothers' smoking during pregnancy.

Fig. 1 Smoking during pregnancy 


\section{$2^{\text {nd }}$ World Conference On Future Of EDUCATION}

BRUSSELS, BELGIUM

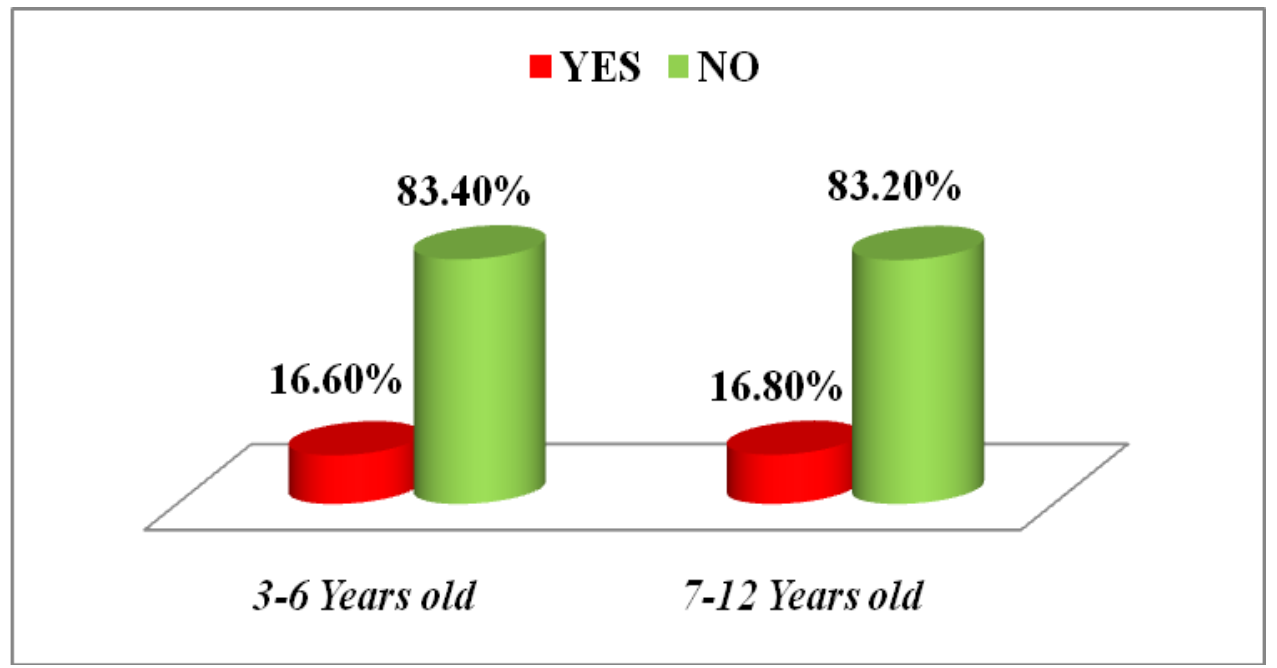

The analysis of the data shows that in both age groups, every sixth woman or approximately $17 \%$ of the respondents smoked cigarettes during pregnancy. The data are graphically presented in fig. 1 .

Turning children into passive smokers in their womb can trigger a number of health problems, including cardiovascular problems at some point in a child's life. If parents are aware of future health risks, properly and well informed about the consequences, both in the early stages of the child's life and in the future, they would not allow themselves to expose their child to passive smoke or at least a large part of them would reduce this risk.

The benefits of breastfeeding are many and common, but it can harm a child's health if a breastfeeding woman smokes, consumes alcohol or caffeinated beverages.

Fig. 2 Smoking during breastfeeding 


\section{$2^{\text {nd }}$ World Conference On Future Of EDUCATION}

BRUSSELS, BELGIUM

11-13 September 2020

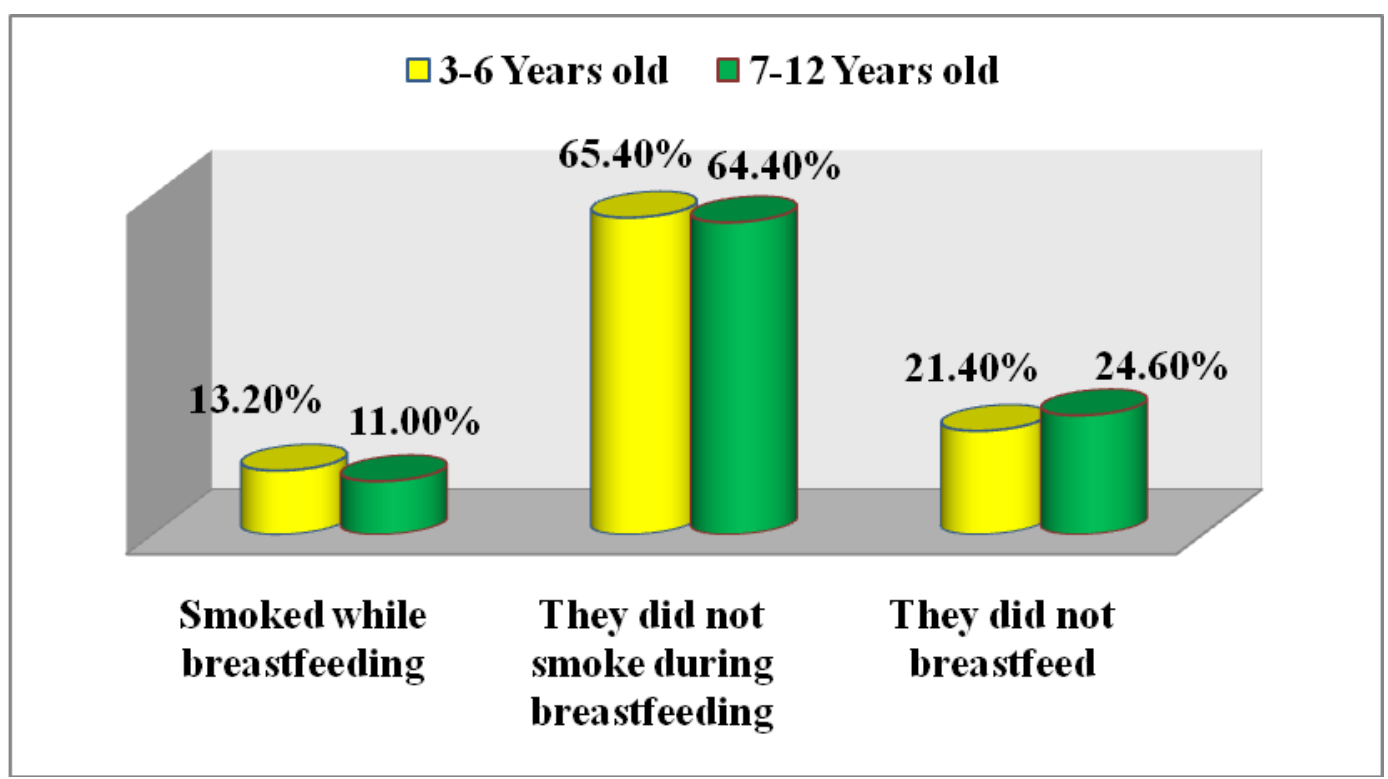

The analysis of the data shows that $13.2 \%$ of the mothers of 3-6-year-old children continued to smoke during breastfeeding. Although with a lower relative share, the results in the age group 7-12 years are similar and show that $11 \%$ of mothers also used tobacco products while breastfeeding their children.

The study found that there was a statistically significant relationship between smoking during pregnancy and during breastfeeding $(\mathrm{p}<0.05)$. The average rank of the amount of cigarettes used during lactation, in the group of smokers, was statistically significantly higher than in the group of non-smokers. These data show that children exposed to tobacco smoke in utero are subjected to passive smoking during breastfeeding.

The study also found a statistically significant relationship between smoking during pregnancy and the presence and duration of breastfeeding. $(\mathrm{p}<0.05)$. The duration of breastfeeding in the smoking group was statistically significantly shorter than in the nonsmoking group. Non-smokers breastfeed statistically significantly more than smokers. At the same time, the study found that the average rank of the number of cigarettes smoked during breastfeeding increases depending on the number of cigarettes smoked during pregnancy.

The role of passive smoking is essential for the future cardiovascular risk in children. On the one hand, children whose mothers smoked during pregnancy are in fact passive smokers. On the other hand, some of them are exposed to the harmful effects of tobacco smoke during breastfeeding. The likelihood of these children being exposed to passive smoking at home, as well as in their friendly environment, the likelihood of early smoking in adolescence puts them in front of a serious CVR with prolonged exposure.

Specialists in the field of children's health (Чачи et al., 2018) report that the indirect exposure to tobacco smoke in children is carried out by the clothes of smokers, the interior of the home and in cars, and that children are more vulnerable because they breathe more often and thus receive more chemicals per kilogram of weight. The authors report evidence that "the total dose of nicotine that children of smoking parents receive is between 60 and 150" actively smoked cigarettes "per 1 year." 


\section{$2^{\text {nd }}$ World Conference On Future of EDUCATION}

BRUSSELS, BELGIUM

11-13 September 2020

Fig. 3. Parents' smoking at home, in the presence of children

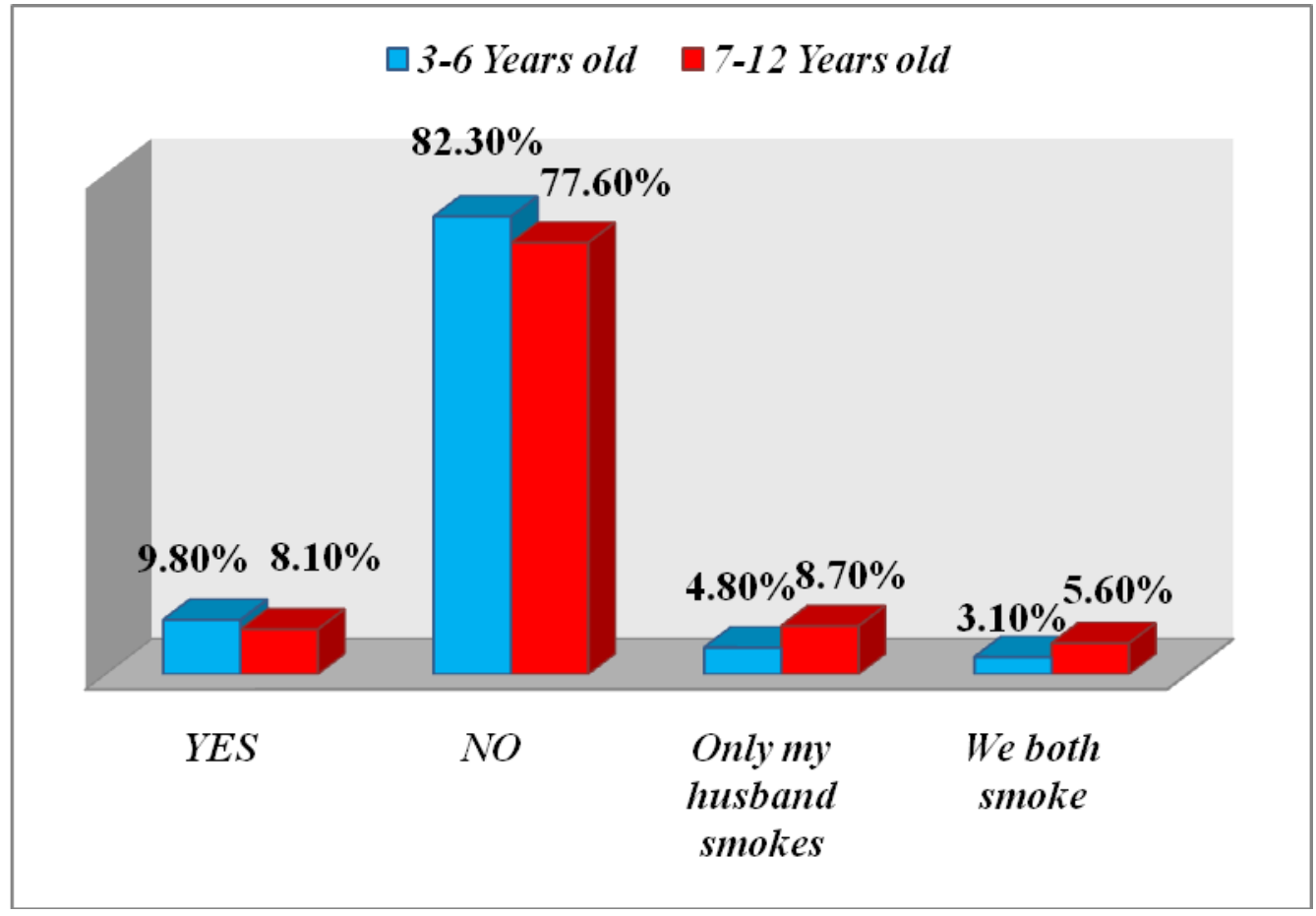

In the course of the survey, respondents were asked whether they smoked in the presence of their child and whether they allowed smoking in the home. The highest for both age groups are the relative shares of those who did not smoke in the presence of their children - $82.30 \%$ and $77.60 \%$, respectively. In second place, among 3-6-year-old children, is the relative share of mothers who continued to smoke in the presence of their child - respectively $9.80 \%$, and in 7-12-year-olds in second place $(8.70 \%)$ is the relative share of fathers who continued to smoke. The lowest, for both age groups, are the relative shares of the respondents, who answered that they both continued to smoke $-3.1 \%$ and $5.6 \%$, respectively. The data are graphically presented in fig. 3.

The current study, in children aged 3-6 years, confirms the data from the National Representative Survey conducted by NCPHP, which found that at this age every fifth child is exposed to passive smoking at home (Манолова et al., 2014).

Despite the relatively high share of respondents who do not expose their children to the negative effects of tobacco smoke, the relative share of mothers and fathers who continue to smoke in the presence of their children after birth is also high. These negative trends in parental smoking are worrying, as these children may have been subjected to passive smoking during fetal development. The negative factor has continued its impact after birth and breastfeeding, and continues in the further upbringing and education of children.

Studies on the impact of secondhand smoke on the health and development of children prove that the risk of pathology compared to adults is 2 to 4 times higher. The reasons for this 


\title{
$2^{\text {nd }}$ World Conference On Future Of EDUCATION
}

\author{
BRUSSELS, BELGIUM
}

11-13 September 2020

are the anatomical and functional immaturity of the respiratory system, increased sensitivity to cigarette smoke, more frequent breathing, which contributes to greater inhalation of cigarette smoke at the same exposure with adults. A significant problem is the inability of the youngest to leave the room. Smoking in parents is an important predictor of smoking in children. Children of parents who smoke are more likely to smoke than children whose parents do not smoke (Манолова et al., 2014. Александров et al., 2012. Тютюнопушене и бременност).

Fig. 4. Awareness of mothers about the harm of passive smoking of the fetus and child

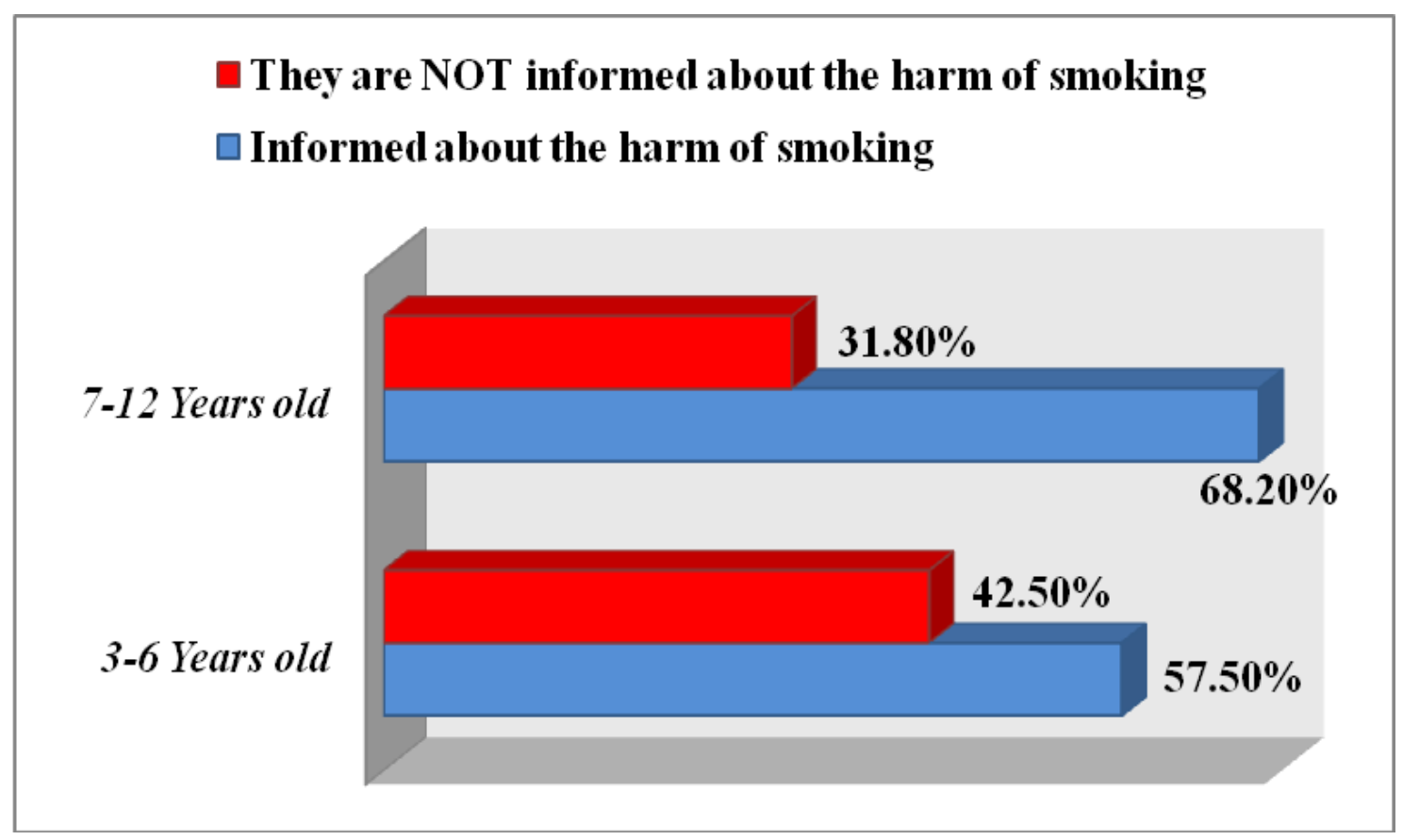

In the study, respondents were asked if they were informed about the risks of secondhand smoke for their child, both during pregnancy and during upbringing. The highest is the relative share (57.5\% for 3-6 year olds and $68.2 \%$ for $7-12$ year olds respectively) of the respondents who claim to have been informed. $42.50 \%$ of parents of 3-6 year olds and $31.8 \%$ of 7-12 year olds gave a negative answer and stated that they were not informed about the risks of smoking during pregnancy and passive smoking of children after birth. The data are presented in fig. 4.

In our study, we set ourselves the task to study the knowledge that respondents have about the negative effects and risks to the fetus and the future health of children from secondhand smoke.

The risks of secondhand smoke are numerous and scientifically proven. Prenatal smoking leads to premature birth and the birth of low birth weight babies. The Syndrome of Sudden Infant Death is also associated with maternal smoking. It has adverse effects in utero on the respiratory and immune systems, and is subsequently associated with more frequent 


\section{$2^{\text {nd }}$ World Conference On Future Of EDUCATION}

\section{BRUSSELS, BELGIUM}

11-13 September 2020

illness in infants and frequent infections of the respiratory system, middle ear, asthma in children and students. The effects on the cardiovascular system are also known - reduced aortic elasticity, increased thickness of the intima-medium of the carotid artery. Passive smoking is also associated with impaired lipoprotein levels and the onset of early atherosclerosis, as well as with an increase in heart rate and blood pressure and the development of diabetes. Passive smoking also has an effect on the nervous system - on psychomotor development and cognitive abilities. In 2017, the connection between smoking in parents and genetic changes in children leading to leukemia was described (Василевски et al., 2004. Коларова-Янева et al., 2013. Константинова, 2011. Попова et al., 2016. Чачи et al., 2018. De Smith et al., 2017. Тютюнопушене и бременност.).

The analysis of our data shows that parents are not well informed about the risks of secondhand smoke, the available knowledge is partial and insufficient. Turning children into passive smokers can trigger a number of health problems, including cardiovascular problems at some point in a child's life. If parents are aware of future health risks, properly and well informed about the consequences, both in the early stages of the child's life and in the future, they would not allow themselves to expose their child to secondhand smoke or at least a large part of them would reduce this risk.

There is a need for health education on issues related to secondhand smoke in children. The conduct of health education and prevention of patients and their relatives by nurses is regulated in Ordinance №1 of 08 February 2011 on the professional activities that nurses, midwives, associate nurses and health care assistants may perform on assignment and independently. Here the role of the nurse for the future health and development of children is crucial (Наредба №1, 2011. Попова, 2020. Georgieva, 2017. Попова et al., 2015, В).

Health education should be comprehensive, starting with children from kindergartens and continuing in schools, in preparation for future parenthood. To be held in the counseling office when the parents are expecting their future child and to continue in the outpatient medical care in the upbringing and education of the newborn and the child at home.

Reducing the impact of risk factors in childhood would have a beneficial effect on the health of the whole population, and this can be achieved through a multidisciplinary approach, namely - pooling the efforts and potential of nurses in pre-hospital care and in schools and kindergartens, and the active assistance of the family, pedagogues and the state. 


\section{$2^{\text {nd }}$ World Conference On Future of EDUCATION}

\section{BRUSSELS, BELGIUM}

11-13 September 2020

\section{Conclusion}

1. In approximately $17 \%$ of respondents smoking begins in their womb, in $12 \%$ it continues during breastfeeding, and $18 \%$ of children aged 3-6 years and $22 \%$ aged $7-12$ years are exposed to passive smoking in at home.

2. Children exposed to tobacco smoke in utero are subjected to passive smoking and during breastfeeding.

3. There is a need for health education and education for parents on issues concerning passive smoking in children. Approximately $40 \%$ of them are not informed about the risks of passive smoking, and the available knowledge is partial, insufficient or incorrect.

\section{References}

1. De Smith, A., Kaur, M., Gonseth, S. Alyson Endicott, A., Selvin, S., Zhang, L., Roy, R., Shao, X., Hansen, H., Kang, A., Walsh, K., Dahl, G., McKean-Cowdin, R., Metayer, C., Wiemel, J. (2017). Correlates of Prenatal and Early- Life Tobacco Smoke Exposure and Frequency of Common Gene Deletions in Childhood Acute Lymphoblastic Leukemia. Cancer Res. 2017 Apr 1; 77(7), 1674-1683.

2. Georgieva, S., Kantareva, P., Terzieva, A., Dimitrova, A. (2017). Training and professional competencies of the nurse. International journal Knowledge, vol. 20 № 4, 2063-2068.

3. Merdjanova E, Petrova G, Kulina Hr. (2016). A research of the parents opinion regarding the physical activity of their children (11, 12 and 13 years old). Science \& Technologies, Vol. VI, (7), 107-113.

4. Meredzhanova E, Petrova G, Kulina Hr, Lalova V. (2019). A research of adolescents physical activity and eating habits during their free time in city of Plovdiv, Bulgaria. Journal of IMAB, 25 (4): 2713-2717.

5. Александров, А., Бубнова, М., Кисляк, О., Конь, И., Леонтьева, И., Розанов, В., Стародубова, А., Щербакова, М. (2012). Профилактика сердечно-сосудистых заболеваний в детском и подростковом возрасте. Российские рекомендации. Российский кардиологический журнал № 6 (98), Приложение 1, 4-40.

6. Борисов, В., С. Попова, Л. Георгиева, К. Шопова. (1998). Промоция на здравето. София.

7. Василевски, Н., Тулевски, Б., Котаров, Г. (2004). Ръководство за предотвратяване и ограничаване на тютюнопушенето. София, М3, НЦООЗ.

8. Георгиева, С. Рискови фактори при деца в България. - Източник: http://www.sustz.com/Proceeding08/Papers/MEDICINE/Georgieva_Stela.pdf

9. Иванов, Е. (2015). Промоция на здравето в училищна възраст. Автореферат на дисертационен труд за присъждане на образователна и научна степен „доктор”. София. 


\section{$2^{\text {nd }}$ World Conference On Future Of EDUCATION}

\section{BRUSSELS, BELGIUM}

11-13 September 2020

10. Коларова-Янева, Н., Господинов, К., Тишева, С., Ангелова, М. (2013). Артериална хипертония и възраст. Наука Пулмология, 2, 26-27.

11. Константинова, М. (2011). Нови акценти в разбирането за диагнозата, етиологията, патогенезата и превенцията на метаболитния синдром в детска възраст. Педиатрия, 1, 7-9.

12. Манолова, А., Костадинова, К., Цолова, Г., Димитров, П., Аврамов, Т., Тафраджийска, М., Евстатиева, К. (2014). Интервенционални мерки за намаляване на риска за здравето на децата от пасивно тютюнопушене. Практическа педиатрия, 7, 14-17.

13. Наредба №1 от 08 февруари 2011 г. за професионалните дейности, които медицинските сестри, акушерките, асоциираните медицински специалисти и здравните асистенти могат да извършват по назначение и самостоятелно. Издадена от Министерството на здравеопазването Обн. ДВ. бр. 15 от 18 Февруари 2011 г., изм. ДВ. бр. 50 от 1 Юли 2011 г. Source: http://www.mh.government.bg/media/filer_public/2015/04/17/naredba1-ot-08-02-

2011g-profesionalni-deinosti-po-naznachenie-ili-samostoiatelno.pdf

14. Попова, Т., Богданова, К., Георгиева, С., Димитрова, А. (2015, В). Необходимост от обучение на пациенти със сърдечно-съдова недостатъчност. Тридесет и шеста научно-технологична сесия Контакт. София (30.10.2015). Гражданска идея в действие. Сборник статии. Темто, 247-253.

15. Попова, Т. (2020). Рискови фактори за сърдечно-съдови заболявания при деца и юноши - промоция, превенция и профилактика. Автореферат на дисертационен труд за присъждане на образователна и научна степен „доктор”. София.

16. Попова, Т., Бикова, П. (2017). Необходимость сотрудничества педагогов и медицинских специалистов в борьбе с сьрдечно-сосудистыми заболеваниями. Общество и образование в XXI веке: опыт, традиции, перспективы (Седьмые Лозинские чтения). Международной научно-методической конференции (24-27 апреля 2017 г.), г. Сочи. Часть I. Псков, 44-49.

17. Попова, Т., Богданова, К., Благоева, Д., Георгиева, С. (2015, А). Семейната среда и ролята й за превенция на сърдечно-съдовия риск при деца от 3 до 7 годишна възраст. Национална конференция на специалистите по здравни грижи. Сборник статии. Монтана, 94-106.

18. Попова, Т., Стамболова, И., Димитрова, А. (2016). Пасивното тютюнопушене и кардиоваскуларният риск при деца на възраст от 3 до 11 години. Здравни грижи, бр. $4,14-19$.

19. Торньова, Б., Шопов, Д. (2008). Формиране на здравни навици и умения в контекстна на семейните отношения. Управление и образование, том IV (3), 131 136.

20. Тютюнопушене и бременност.

Source: https://www.mh.government.bg/media/filer_public/2015/04/08/tyutyunopushene-ibremennost.pdf

21. Чачи, Ер., Господинова, Б., Переновска, П. (2018). Пасивното пушене - враг на детското здраве. Практическа педиатрия, 10, ноември 2018, 26-30. 